\title{
PERBEDAAN HASIL BELAJAR DALAM PEMBELAJARAN YANG MENGGUNAKAN DAN TIDAK MENGGUNAKAN TEKNIK PEMBELAJARAN PROBING PROMPTING
}

\author{
Prihatin Sulistyowati, Jekta Lupita Sari, Didik Iswahyudi \\ PGSD Universitas Kanjuruhan Malang \\ prihatinsulistyowati@unikama.ac.id
}

\begin{abstract}
Abstrak
Penelitian bertujuan untuk mengetahui perbedaan hasil belajar pembelajaran yang menggunakan dan tidak menggunakan teknik pembelajaran probing prompting di kelas V SDN Tanjungrejo 01. Penelitian menggunakan Quasy Eksperimental Design. Populasi dari penelitian ini adalah seluruh siswa kelas V. Analisis data menggunakan analisis data kuantitatif. Uji analisis data meliputi: uji instrumen, uji prasyarat analisis, dan uji hipotesis. Hasil penelitian menunjukkan bahwa: (1) hasil belajar peserta didik kelas eksperimen mempunyai nilai rata-rata $(84,53)$. (2) hasil belajar peserta didik kelas kontrol mempunyai nilai rata-rata $(64,22)$. Hal tersebut dibuktikan dengan menggunakan uji independent sample t-test yang menunjukkan jika dilihat dari signifikan lebih kecil dari 0,05 , yaitu 0,00 . $(0,05>0,00)$ jadi pada penelitian ini dapat disimpulkan bahwa ada perbedaan hasil belajar pembelajaran yang menggunakan dan tidak menggunakan teknik pembelajaran probing prompting.
\end{abstract}

Kata kunci: Probing prompting, hasil belajar, teknik pembelajaran

\begin{abstract}
The study aims to determine the differences in learning outcomes that use and do not use probing prompting learning techniques in class V SDN Tanjungrejo 01. The study uses the Quasy Experimental Design. The population of this study is all fifth grade students. Data analysis uses quantitative data analysis. Data analysis tests include: instrument testing, prerequisite test analysis, and hypothesis testing. The results showed that: (1) the learning outcomes of the experimental class students had an average value (84.53). (2) learning outcomes of control class students have an average value (64.22). This is evidenced by using the independent sample t-test which shows that it is significantly smaller than 0.05, which is 0.00. $(0.05>0.00)$ so in this study it can be concluded that there are differences in learning outcomes that use and do not use probing prompting learning techniques.
\end{abstract}

Keyword : Probing prompting, learning result, learning techniques 


\section{PENDAHULUAN}

Kurikulum 2013 adalah pembelajaran yang didesain untuk mengembang kan potensi peserta didik, bertujuan untuk mewujudkan generasi bangsa Indonesia yang bermartabat, beradab, berbudaya, berkarakter, beriman dan bertakwa kepada Tuhan Yang Maha Esa, berakhlak mulia, sehat, berilmu, cakap, kreatif, mandiri, menjadi warga negara yang demokratis, dan bertanggung jawab (Kemendikbud, Nomor 18A, 2013). Menurut Trianto (2017:06) pembelajaran tematik merupakan salah satu model dalam pembelajaran terpadu (integrated instruction) yang merupakan suatu sistem pembelajaran yang memungkinkan siswa, baik secara individual maupun kelompok, aktif menggali dan menemukan konsep serta prinsip-prinsip keilmuan secara holistik, bermakna, dan autentik.

Pembelajaran kurikulum 2013 menggunakan tematik integratif. Menurut Mulyoto (2013:118) pembelajaran tematik integratif adalah pembelajaran yang mengintegrasikan beberapa mata pelajaran dalam satu tema. Integrasi tersebut dilakukan dalam tiga hal, yaitu integrasi sikap, ketrampilan, dan pengetahuan dalam proses pembelajaran. Dalam pembelajaran integratif pada satu hari pembelajaran terdapat beberapa mata pelajaran yang dapat digabungkan antara lain yaitu PPKN, Matematika, Bahasa Indonesia, IPA dan IPS. Pelaksanaan pembelajaran tematik juga memerlukan kesiapan guru meliputi aspek behavioral readiness (kesiapan perilaku), emotive-ettitudinal (kesiapan sikap dan emosi), cognitive (kesiapan kognitif) (Wangid:2014)

Dalam proses pembelajaran peserta didik didorong untuk mengembangkan keaktifan dan kemampuan berfikir. Untuk mencapai tujuan pendidikan yang maksimal, peran guru sangat penting. Guru diharapkan lebih kreatif, inovatif, (Ulya:2012) dan memiliki cara atau model mengajar yang baik dan mampu memilih model pembelajaran yang tepat dan sesuai dengan konsep-konsep mata pelajaran yang akan disampaikan kepada peserta didik. Probing prompting termasuk dalam teknik pembelajaran aktif. Keaktifan belajar dalam pembelajaran probing promting mendorong proses berpikir serta melatih siswa untuk berpikir kritis (Susanti:2017). Probing prompting merupakan pembelajaran dengan cara guru menyajikan serangkaian pertanyaan yang sifatnya menuntun dan menggali sehingga terjadi proses berpikir yang mengaitkan pengetahuan dan pengalaman 
peserta didik dengan pengetahuan dan pengalaman peserta didik dengan pengetahuan yang baru (Shoimin, 2014:126). Pembelajaran yang berbasis proses berpikir akan menuntun siswa pada kemampuan berpikir kritis sehingga mampu memecahkan permasalahan sehingga dapat dikatakan probing promting dapat melatih kemampuan siswa untuk memecahkan masalah (Mustika:2017)

Proses pembelajaran yang telah dilaksanakan guru sudah menerapkan pendekatan scientific, namun pada saat pembelajaran berlangsung peserta didik kurang aktif dalam belajar. Rendahnya aktivitas peserta didik dalam pembelajaran di kelas serta kurangnya keberanian peserta didik saat menjawab pertanyaan pada saat guru menunjuk peserta didik untuk menjawab sehingga guru perlu memotivasi dahulu dengan memberikan nilai tambahan. Selain itu, pada saat pembelajaran di dalam kelas pembelajaran tidak berlangsung dengan kondusif karena peserta didik lebih suka ribut dengan temannya dari pada mendengarkan penjelasan guru.

Penelitian ini untuk menguji apakah ada perbedaan hasil belajar siswa setelah proses pembelajaran yang menggunakan dan tidak menggunakan teknik pembelajaran probing-prompting. Perbedaan tersebut akan menunjukkan keberhasilan atau tidaknya dalam pembelajaran

\section{METODE PENELITIAN}

Jenis penelitian yang digunakan dalam penelitian ini adalah kuasi eksperimen dengan desain penelitian berupa kelompok kontrol non-ekuivalen (nonequivalent control group design). Sebagaimana yang dijelaskan Sugiyono (2012:116) design ini mempunyai kelompok kontrol, tetapi tidak dapat berfungsi sepenuhnya untuk mengontrol variabel-variabel luar yang mempengaruhi pelaksanaan eksperimen. Dalam penelitian ini dilakukan pretest dan posttest terhadap kelas kontrol dan kelas eksperimen untuk dapat mengetahui perbedaan dari treatment yang diberikan. Rancangan penelitian digambarkan pada tabel 1 berikut ini: 
Tabel 1 Rancangan Penelitian

\begin{tabular}{ccccc}
\hline & Pretest & Perlakuan & Posttest & Subyek \\
\hline $\mathbf{R}$ & $\mathbf{O}_{\mathbf{1}}$ & $\mathbf{X}_{\mathbf{1}}$ & $\mathbf{O}_{\mathbf{2}}$ & (Eksperimen) \\
\hline $\mathbf{R}$ & $\mathbf{O}_{\mathbf{3}}$ & - & $\mathbf{O}_{\mathbf{4}}$ & (Kontrol) \\
\hline & & & & \\
\end{tabular}

Populasi yang digunakan sama dengan sampel karena menggunakan teknik sampel jenuh, maka populasi dan sampelnya adalah 64 peserta didik kelas V A dan B SDN Tanjungrejo 1. Data yang digunakan dalam penelitian ini terdiri dari data observasi, tes tulis dan dokumentasi. Sedangkan instrumen yang digunakan dalam penelitian ini adalah instrumen perlakuan, instrumen pengukuran dan instrumen observasi. Instrumen pengukuran adalah soal tes (pretest dan posttest) yang berupa soal pilihan ganda yang telah divalidasi oleh tim ahli dan dilakukan uji coba terlebih dahulu.

Analisis data dilakukan melalui tahap pengujian yakni uji normalitas untuk menguji normalitas distribusi data, uji homogenitas untuk menguji homogenitas sampel, uji beda dua rata-rata untuk mengetahui adanya perbedaan kemampuan awal peserta didik, dan terakhir pengujian hipotesis untuk menguji kebenaran hipotesis yang telah dirumuskan.

\section{HASIL PENELITIAN}

Sebelum instrumen dapat digunakan untuk mengambil data maka instrumen diuji terlebih dahulu dengan uji validitas, realibilitas, tingkat kesukaran, dan daya beda, dengan hasil sebagai berikut: (1) Uji Validitas, soal tes yang dipersiapkan 30 soal berupa pilihan ganda. setelah diuji validitas soal tes maka yang dinyatakan valid adalah 21 soal. Soal yang digunakan sebanyak 20 soal. Soal tersebut untuk pretest dan postest . (2) Uji Reliabilitas, hasil uji reliabilitas menunjukkan instrumen reliabel dengan hasil Cronbach' Alpha sebesar $0,979 \leq \mathrm{r} 11<1,00$. (3) Uji tingkat kesukaran soal, sebanyak 20 soal terdapat soal dengan kategori mudah 1, sedang 17, dan 2 sukar. (3) Uji Daya Beda Butir Soal, hasil uji daya beda butir soal menunjukkan sudah diatas kriteria yaitu $\geq 0,25$, sehingga dapat dikatakan sudah memenuhi. 
Dalam penelitian ini data kemampuan kognitif awal peserta didik diperoleh melalui pretest yang diperoleh sebelum melakukan proses eksperimen atau pemberian perlakuan. Berdasarkan hasil perhitungan melalui program SPSS diketahui bahwa nilai tertinggi untuk kelas kontrol dan eksperimen adalah 100, sedangkan nilai terendah kelas kontrol 40 dan eksperimen 45, selain itu dapat dideskripsikan bahwa kemampuan awal kelas eksperimen lebih tinggi dari pada kelas kontrol, hal ini dapat dilihat dari kelas eksperimen sebesar 65. Sedangkan rerata kelas kontrol sebesar 60. Akan tetapi untuk mengetahui lebih lanjut apakah kemampuan awal peserta didik kelas kontrol dengan kelas eksperimen tidak terdapat perbedaan perlu dilakukan uji beda rata-rata. Dari uji beda rata-rata kemampuan awal peserta didik dengan menggunakan uji $\mathrm{T}$ diperoleh nilai signifikansi 0.134 yang berarti besar dari 0.05. Berdasarkan dari perhitungan ini dapat diambil kesimpulan bahwa tidak terdapat perbedaan signifikan antara kemampuan awal peserta didik kelas kontrol dengan kelas eksperimen. Adapun kemampuan awal peserta didik kelas kontrol dan kelas eksperimen dapat dilihat melalui tabel 2 dan 3 berikut :

Tabel 2 Deskripsi Nilai Pretest Kelas Kontrol

\begin{tabular}{lc}
\hline \multicolumn{1}{c}{ Deskripsi } & Kelas Kontrol \\
\hline Rata-rata & 60 \\
\hline Standar Deviasi & 10,228 \\
\hline Banyak peserta didik & 32 \\
\hline
\end{tabular}

Sumber: Hasil analisis pengolahan SPSS 22.0

Tabel 3 Deskripsi Nilai Pretest Kelas Eksperimen

\begin{tabular}{lc}
\hline \multicolumn{1}{c}{ Deskripsi } & Kelas Eksperimen \\
\hline Rata-rata & 65 \\
\hline Standar Deviasi & 9,513 \\
\hline Banyak peserta didik & 32 \\
\hline
\end{tabular}

Sumber: Hasil analisis pengolahan SPSS 22.0

Data kemampuan akhir peserta didik diperoleh dari nilai posttest setelah diberi perlakuan metode pembelajaran yang berbeda. Berdasarkan hasil 
perhitungan melalui program SPSS dapat diketahui bahwa nilai minimum kemampuan akhir peserta didik kelas kontrol dan kelas eksperimen adalah 40 dan 45, sedangkan nilai tertinggi 100. Rata-rata kemampuan akhir peserta didik kelas eksperimen lebih tinggi daripada kemampuan akhir peserta didik kelas kontrol, hal ini ditunjukkan rata-rata kemampuan akhir kelas kontrol sebesar 64,22 sedangkan pada kelas eksperimen sebesar 84,54. Adapun kemampuan akhir peserta didik kelas kontrol dan kelas eksperimen dapat dilihat melalui table 4 dan 5 berikut:

Tabel 4 Deskripsi Nilai Posttest Kelas Kontrol

\begin{tabular}{lc}
\hline \multicolumn{1}{c}{ Deskripsi } & Kelas Kontrol \\
\hline Rata-rata & $\mathbf{6 4 , 2 2}$ \\
\hline Standar Deviasi & $\mathbf{1 1 , 6 9 9}$ \\
\hline Banyak peserta didik & $\mathbf{3 2}$ \\
\hline
\end{tabular}

Sumber: Hasil analisis pengolahan SPSS 22

Tabel 5 Deskripsi Nilai Posttest Kelas Eksperimen

\begin{tabular}{lc}
\hline \multicolumn{1}{c}{ Deskripsi } & Kelas Kontrol \\
\hline Rata-rata & 84,53 \\
\hline Standar Deviasi & 16,126 \\
\hline Banyak peserta didik & 32 \\
\hline & Sumber: Hasil analisis pengolahan SPSS 22.0
\end{tabular}

Sebelum melakukan uji hipotesis terlebih dahulu melakukan uji prasyarat yang terdiri dari uji homogenitas dan normalitas. Dalam uji normalitas hasil uji Kolmogorov-Smirnov menunjukkan nilai signfikansi untuk kelas kontrol sebesar 0.136 yang lebih besar dari 0.05. sehingga dapat dikatakan kelas kontrol berdistribusi secara normal. Adapun hasil perhitungan uji normalitas kelas kontrol terdapat pada tabel 6 sebagai berikut:

Tabel 6 Hasil Output One-Sample Kolmogorov-Smirnov Test kemampuan akhir(posttest)

\section{Tests of Normality}

KELAS Kolmogorov-Smirnov ${ }^{\mathrm{a}} \quad$ Shapiro-Wilk




\begin{tabular}{llrrrrrr}
\hline & & Statistic & df & Sig. & Statistic & df & \multicolumn{1}{l}{ Sig. } \\
\hline NILA & KONTROL & .155 & 32 & .050 & .955 & 32 & .204 \\
\cline { 2 - 8 } I & $\begin{array}{l}\text { EKSPERIME } \\
\text { N }\end{array}$ & .150 & 32 & .066 & .937 & 32 & .063 \\
& & & & & & &
\end{tabular}

a. Lilliefors Significance Correction

Sumber: Hasil analisis pengolahan SPSS 22.0

Untuk uji homogenitas data pretest kelas kontrol dan kelas eksperimen untuk mengetahui apakah nilai pretest kelas kontrol dan kelas eksperimen homogen atau tidak. Uji statistik berbantuan SPSS 22.0 for windows yang digunakan adalah uji levene dengan mengambil taraf signifikansi $=0,05$. Kriteria pengujiannya adalah $\mathrm{H}_{0}$ diterima jika nilai signifikan $>0,05$ dan $\mathrm{H}_{0}$ ditolak jika nilai signifikansi $<0,05$. Adapun hasil uji homogenitas dapat dilihat pada tabel 7 sebagai berikut:

Tabel 7 Hasil Uji Homogenitas Pretest Kelas Kontrol dan Kelas Eksperimen

\begin{tabular}{cccc}
\hline \multicolumn{4}{c}{ Test of Homogeneity of Variances } \\
\hline \multicolumn{4}{c}{ Nilai Pretest } \\
\hline Levene Statistic & $\mathrm{df1}$ & $\mathrm{df} 2$ & Sig. \\
\hline, 198 & 1 & 62 &, 658 \\
\hline Sumber: Hasil analisis pengolahan SPSS 22.0
\end{tabular}

Dari pengujian normalitas dan juga homogenitas didapat kesimpulan bahwa data berdistribusi secara normal untuk itu dapat langsung diuji hipotesis. Adapun hasil uji hipotesis dapat dilihat pada tabel 8 sebagai berikut:

Tabel 8 Hasil Uji t Hipotesis

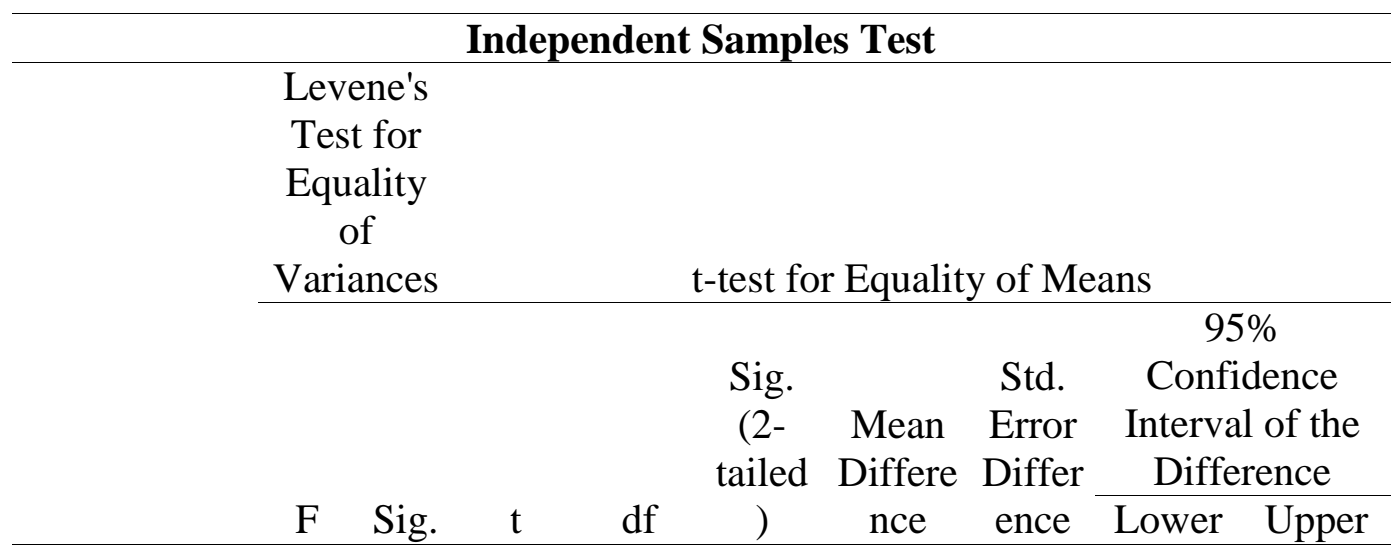




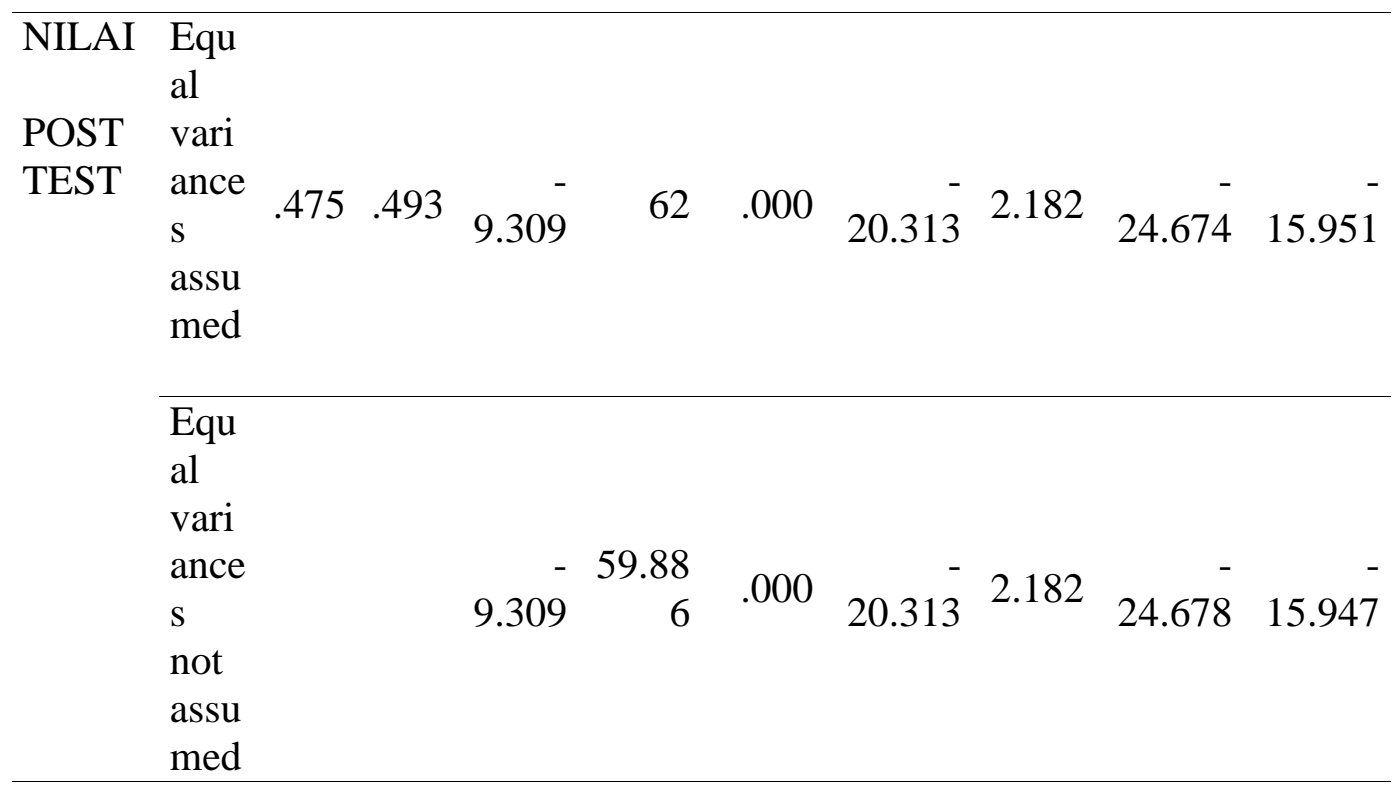

Sumber : Hasil analisis menggunakan SPSS 22.0

Berdasarkan tabel 8 tersebut diketahui bahwa nilai hasil belajar kognitif peserta didik akhir (posttest) kelas kontrol dan kelas eksperimen 0,00 karena 0,00 $<0,05$ maka dapat disimpulkan bahwa $\mathrm{H}_{0}$ ditolak atau ada perbedaan hasil belajar peserta didik akhir (posttest) kelas kontrol dan kelas eksperimen. Berdasarkan hal tersebut maka dapat disimpulkan pula bahwa ada perbedaan pembelajaran yang menggunakan dan tidak menggunakan teknik probing prompting terhadap hasil belajar peserta didik.

\section{KESIMPULAN DAN SARAN}

Berdasarkan hasil penelitian dapat disimpulkan bahwa ada perbedaan pembelajaran yang menggunakan dan tidak menggunakan teknik pembelajaran probing prompting terhadap hasil belajar siswa kelas V SDN Tanjungrejo 01 Kota Malang pada Tema ekosistem dengan tingkat signifikansi $00<0,05$.

Pembelajaran menggunakan model probing promting sebaiknya sering digunakan guru saat mengajar sebagai teknik pembelajaran yang bervariatif sehingga pembelajaran akan lebih maksimal. 


\section{DAFTAR PUSTAKA}

Diasputri A, Nurhayati S, Sugiyo W.2015. Pengaruh Model Pembelajaran Probing-Prompting Berbantuan Lembar Kerja Berstruktur Terhadap Hasil Belajar. Jurnal Inovasi Pendidikan Kimia.

Fauziah.M, Mintohari.2017.Pengaruh Model Pembelajaran Probing-Prompting Terhadap Hasil Belajar Pada Tema 8 (Ekosistem) Siswa Kelas V SDN Wiyung I Surabaya. JPGSD Volume 05 No.03.

Huda, Miftahul. 2013. Model-model Pengajaran dan Pembelajaran. Yogyakarta: Pustaka Belajar.

Kemendikbud 2013, Nomor 18 A. Tentang Implementasi Kurikulum.

Kusuma AT, Indrawati, Harijanto A.2015.Model Discovery Learning Disertai Teknik Probing Prompting Dalam Pembelajaran Fisika Di MA.Jurnal Pendidikan Fisika, Vol. 3 No.4, Maret 2015, hal 336-341.

Mulyoto. 2013. Strategi Pembelajaran Di Era Kurikulum 2013.Jakarta: Prestasi Pustakarya.

Mustika Helma, Buana Lindra.2017.Penerapan Model Pembelajaran Probing Promting Terhadap Kemampuan Pemecahan Masalah Matematika Siswa. Journal of Mathematics Education and Science. SSN: 2579-6550 (online) 2528-4363 (print) Vol. 2, No. 2. April 2017.

Nugroho, Agung M. (2015). Penggunaan Metode Tutor Teman sebaya untuk meningkatkan hasil belajar siswa kelas IV pada pembelajaran Tematik Tema 9 Subtema 1 Pembelajaran 6 di SDN Kebonsari III Kota Malang tahun pelajaran 2014/2015. Skripsi tidak diterbitkan. FIP Universitas Kanjuruhan Malang.

Shoimin, Aris. 2014. 68 Model Pembelajaran Inovatif. Yogyakarta: AR-RUZZ MEDIA.

Siregar HL, Mulyana R.2016. Penerapan Metode Pembelajaran Probing Prompting Untuk Meningkatkan Aktivitas Dan Hasil Belajar Siswa Pada Mata Pelajaran Konstruksi Bangunan Di Kelas X Program Keahlian Teknik Gambar Bangunan SMK Negeri 1 Stabat. JURNAL EDUCATION Buuilding. Volume 2, Nomor 1 Juni 2016: 1-10, ISSN :2477-4898.

Sugiyono. 2012. Metode Penelitian Kuantitatif Kualitatif dan R\&D. Bandung: Alfabeta.

Susanti ,Elsa.2017. Penerapan Model Pembelajaran Probing-Prompting Untuk Meningkatkan Kemampuan Berpikir Kritis Matematis Siswa Kelas XI.IPA MAN 1 Kota Bengkulu. Jurnal Pendidikan Matematika Raflesia. Vol. 2 No. 1 Tahun 2017. 
Trianto .2013. Mendesain model pembelajaran inovatif-progresif. Jakarta:PT Bumi Aksara.

Ulya H, Masrukan, Kartono.2012. Keefektifan Penerapan Model Pembelajaran Kooperatif Tipe Probing-Promting dengan Penilaian Produk. Unnes Journal of Mathematics Education 1(1) (2012) ISSN No 2252-6927.

Wangid MN,Mustadi A,Erviana YV, Arifin S.2014.Kesiapan Guru SD Dalam Pelaksanaan Pembelajaran Tematik-Integratif Pada Kurikulum 2013 Di DIY. Jurnal Prisma Edukasia, Vol.2 No.2 2014. 